\title{
Happiness in the world? (Pascal before Port-Royal)
}

\author{
Camille Akmut
}

May 15, 2020

\begin{abstract}
Various events and people in the life of Pascal during his "worldly" period (here significantly revised, extended).
\end{abstract}




\section{People}

Jacqueline : the religious sister

Gilberte : the older, later married sister

Mersenne : 17th c. "router" of science... (Mersenne primes, that is him)

Christina : Queen of Sweden, patron of the sciences (possibly genderqueer)

Roberval : Professor of mathematics at the College de France

Desargues : another important mathematician of the time (geometry)

Saint-Cyran : founder of 'Jansenism', i.e. importer of Jansen's ideas in France

Jansen : Dutch. Strict Christian, reader of Augustine (S-C's buddy)

\section{Table of events}

\begin{tabular}{|l|l|}
\hline 1640 & 'Essay on conics' \\
1641 & Gilberte marries (Perier) \\
1642 & Machine for arithmetic [0] \\
1644 & Pascal shows off his Machine to the Prince of Conde [1] \\
1646 & Etienne Pascal injured. \\
1647 & First conversion [2] \\
1648 & Barometer experience [3] \\
1649 & Patents granted for the arithmetic machine \\
1651 & Death of his father. Inheritance \\
1652 & Jacqueline goes to Port-Royal [4] \\
1652 & Letter to the Queen of Sweden. \\
1654 & Vision. Final conversion \\
$1655 ; 56$ & Port-Royal; Lettres provinciales... \\
\hline
\end{tabular}

[0] Gilberte's biography (repeated by Brunschvicg/Boutroux, cf. Oeuvres 1 : 293).

[1] Brunschvicg/Boutroux vol. $3: 26$.

[2] Taton 1962.

[3] New Cambridge Early Modern History 4 : 157.

[4] Brunschvicg/Boutroux vol. 2 : front page.

\section{Table of events (2)}

\begin{tabular}{|l|l|}
\hline 1640 & Jansen, Augustinus. \\
$1643-1715$ & King Louis XIV's reign. \\
mid-1640's & Saint-Cyran, Letters... \\
1648 & Peace of Westphalia (end of the Thirty Years War). \\
1648 & Mersenne dies. \\
1650 & Descartes dies. \\
1654 & Letters from Jansen to Saint-Cyran published. \\
1654 & Christina of Sweden abdicates. \\
\hline
\end{tabular}


Brunschvicg/Boutroux put Pascal's "wordly" period between the death of his father and his final conversion ${ }^{1}$, ie. from about 1651 to 1654 .

But, this should rather be considered its height (being the last years before his retreat in Port-Royal).

This period can be extended to include most of his teens, twenties (with an interruption consisting of his first conversion).

\section{I - Early success (the boy genius)}

A basic overview of the field of mathematics during the times, and spaces, of Pascal can be gathered from the The New Cambridge Modern History :

Roberval, Desargues and Fermat are mentioned there as Descarte's "able rivals", while Gassendi had appeared just before. (Vol. 4, 48.)

Desargues plays an important role in the context of Pascal's early mathematical successes :

Jean Dieudonne, in his history of algebraic geometry, noted

"The originality of Desargues was that through central projection he found a way to move from particular cases of a theorem to its general formulation, for instance by obtaining general theorems on conics based on theorems relating to circles : thus Pascal, who was heavily influenced by the ideas of Desargues, could demonstrate his famed theorem on the hexagon" ${ }^{2}$

Here, a succinct description of Pascal's Essay on conics, implied :

$P_{1} P_{2} P_{3} P_{4} P_{5} P_{6}:$ a hexagon, "inscribed" in a conic,

\footnotetext{
${ }^{1}$ Brunschcq/Boutroux vol. $3: 112$.

${ }^{2}$ Dieudonne 1974 : 26.
} 
$K\left(P_{1} P_{2} \cap P_{4} P_{5}\right), L\left(P_{2} P_{3} \cap P_{5} P_{6}\right), M\left(P_{3} P_{4} \cap P_{6} P_{1}\right):$ the intersection points "of pairs of opposite sides",

$K, L, M$ lie on the same line (they are "collinear") ${ }^{3}$

- hexagon $=\operatorname{six}($ lat. hexa) sides...

- conic (section) $=$ the intersection of a plane with a cone

(this can be e.g. a circle, being a special case of an ellipse)

- e.g. $P_{1} P_{2}$, or $\mathrm{AB}=$ a side / line

$-\cap=$ intersection [possibly imported from set theory, or the other way around]

- inscribed $\neq$ inside, in (a shape can be in-side another without being inscribed)

Following these first accomplishments, during which he must have been 16-17,

Pascal repeated successes :

- Machine for arithmetic (1642, he is 19 years old $\left.{ }^{4}\right)$,

- barometers and pressure ${ }^{5}$ (1648, he is about 25), from which the namesake unit is derived,

- probabilities ${ }^{6}$, etc. etc..

We skip episodes such as when a 12-year old P. seemingly reinvented parts of maths :

Forbidden by Etienne from learning mathematics, a subject that "fills the mind with such great pleasure", in the fear his son should neglect his education in the humanities, Pascal invented his own mathematical terms e.g. to describe common geometrical shapes, and therefrom derived the rest.

"He begun to dream in his frees hours*; and being alone in a room where he had the habit to go for recreation, he took charcoal and started drawing on the windows, a perfect circle, a triangle whose

\footnotetext{
${ }^{3}$ Adapted from the textbook Geometry by its history, which teaches the subject following, close, historical order. (Desargues's theorem appears just before Pascal's.)

${ }^{4}$ Per Gilberte's biography.

5"Galileo's work was carried on by his pupil Evangelista Torricelli of Florence (1608-47) who constructed a barometer. The description given of it was vague, but it suggested ideas to Pascal which led not only to his barometric experiments, but to proofs of the more elementary propositions relating to the pressure exerted by fluids." (Cambridge modern history $5: 715$ )

${ }^{6}$ eg. Cambridge modern history 5 : 712 ("Before leaving the subject of Pure Mathematics")
} 
sides or angles are similar. (...) Once a terminology agreed upon, he started to create axioms ... and [at some point, finally] reached Euclid's 32nd proposition..."7

[*Meaning : outside of home-schooling.]

Fast-forward to the Pensees, and :

These earlier scientific achievements are what the mature Pascal must mean as part of the category of libido sciendi experiences :

"In the world everything is either lust for the flesh, desire to see

(know), or the hubris of life's conquests :

Libido sentiendi, libido sciendi, libido dominandi."

458 B

8

\section{II - A letter to a Queen}

Perhaps no other document of this entire period speaks so much truth to the state in which Pascal had been at the brink of his final conversion than the letter he sent to Christina of Sweden in 1652, so liquorish and outsized it needs no commentary but itself :

Letter to the Most Serene...

"Madam,

If I had as much health as zeal, I would present myself to Your

Majesty a work of many years, that I dare offer from afar; and

\footnotetext{
${ }^{7}$ Gilberte's biography has been repeatedly called a hagiography.

${ }^{8} \mathrm{~A}$ pensee that Condorcet (found so bad he) removed from his own edition of the Pensees, noting P. struck through it, noting also no one should miss it. (See Condorcet's "eloge"...)
} 
I would not suffer from any other hands than mine the honor of bringing it to the feet of the greatest princess of the world.

This work, Madam, is a machine to do arithmetic...;

and I cannot better describe it than by saying that I put as much work into it than if I knew that one day it would appear before person as august as you.

Yet, Madam, if this had not been my intent, it would be its reward. And, I would consider myself too lucky, if after so many sleepless nights ["veilles"], it could bring Your Majesty just a few moments of satisfaction..." etc. etc..

(If philosophers actually read philosophers, including their patents, and letters such as this one, they would do much better work...)

The sender of this monumental letter known, its object too (the Machine for arithmetic) : its recipient is in fact very fascinating (so much that "the greatest princess of the world" may not have been that much of an exaggeration) :

"Queen Christina of Sweden, ... patron and disciple of Descartes, ...

correspondent of Pascal and Spinoza"

— is more or less her usual description ${ }^{9}$.

She is in turn described by Brunschvicg/Boutroux as Europe's most in-vogue personality... ("la plus en vue") ${ }^{10}$. In other words : an intellectual, ruler, and glamorous.

\footnotetext{
${ }^{9}$ As found in the textbook The Cambridge Modern History (Vol. 5 : 744 (Section "Jesuits and their converts")

${ }^{10}$ Brunschvicg/Boutroux vol. $3: 26$.
} 
It was to this person, no other than the Queen of Sweden, that a 29-year old Pascal decided to send a letter - and what letter.

Christina was fascinating for many other reasons : Of them we are further told :

"She was educated as a male, learning to ride, fence, and shoot;

(...) By 1650 Christina had made it clear she could not marry. This

decision arose from her own identity struggles, which may have been

complicated by psychological and physiological factors." 11

raising the possibility that she may have been genderqueer, or non-straight, or any combination of the above.

In the background of this exchange lies the Thirty Years War (1618-1648), and, later, her abdication in $1654 .^{12}$

\section{III - A visit to a Prince (marketing of the Machine, cont.)}

Before Pascal had "presented" his Machine to the Queen of Sweden, he had already done the same for the Prince of Conde eight years earlier;

At least he had received an invitation to do so, stating when exactly the said Prince was best visited.

It came from a Bourdelot, "French preacher and doctor"13 ("abbot"14). The same had already been involved with (playing intermediaries with) the Queen.

\section{"Monsieur,}

\footnotetext{
${ }^{11}$ Encyclopedia of the Early..., vol. 1.

${ }^{12}$ The chronology provided at the end of volume 5 of The Cambridge Modern History holds 1652 , but this seems to be an error. (Elsewhere in the text, so far as we recall, 1654 is given. In Encyclopedia of the Early... that same date is also repeated.)

${ }^{13}$ Les Lettres de, footnote in the Letter to the Queen.

${ }^{14}$ Oeuvres.
} 
I was speaking to His Highness ["Son Altesse"] yesterday who com-

municated to me his impatience to see your [Machine] ${ }^{15}$. If you will please come tomorrow at 10 in the morning, I believe it will be most convenient to [said Highness]."

(letter from 1644)

"You write mighty well for a philosopher..."

[the Queen likes your stuff, etc.]

(letter from 1652)

[The Prince of Conde must have been Henri II, by that time (does it really matter? $\left.\left.{ }^{16}\right) \ldots\right]$

\section{IV - Pascal's correspondence : social capital (2)}

Pascal did make great, continuous use of his father's vast network of connections (bridging the scientific and political worlds) :

It was through him that he was able to access most of his early supporters including Roberval (who would later act as a seller-demonstrator for the Machine), and interlocutors.

Pascal's network - as can be ascertained from his correspondence - included dozens of important figures of the time;

in addition to already mentioned Fermat, the Queen of Sweden and Prince of Conde :

Mersenne, Descartes, Christiaan Huygens, Christopher Wren,... ${ }^{17}$

A letter sent by Descartes to Mersenne, from December 1647, gives us an insight into these happenings :

\footnotetext{
${ }^{15}$ In this document the Machine is called "roue Pascal".

${ }^{16}$ In 'The Cambridge modern history', old and new, the (various) Princes of Conde are found.

${ }^{17}$ See our bibliography.
} 
"Dear Father [Mersenne]

It has been some time already since M. of Zuylichem has sent me the print by Pascal, for which I thank the author, as it is they who send

it.

\section{From Egmond"}

It is useful to remember that Descartes was then in the Netherlands ${ }^{18}$, having fled France. Hence why Huygens, presumably. But, more importantly :

To sum up what is happening :

1. Descartes via Mersenne discusses Pascal (and likely vice-versa);

2. Huygens ["M. de Zuylichem"], in turn, played intermediaries for Pascal and Descartes;

3. Add whatever intermediary steps this letter required but does not mention.

This is how a highly resourceful network looks like; and what is meant by high social capital : just as an individual may possess economic capital (of which Pascal, bourgeois-noble, had lots of both).

Bourdelot introduced Pascal to the Prince of Conde, and again is mentioned by Pascal in his letter to the Queen of Sweden - B. was "in good favors" with her, we know from Pascal editors ${ }^{19}$.

Pascal before navigating complicated philosophical arguments, knew how to navigate the world...

*** Origins of the Machine for arithmetic? ***

\footnotetext{
${ }^{18}$ See e.g. Cambridge Modern History 4, 779 : "He [descartes] remained in Holland until September 5, 1649 ... At the same time he was in correspondence with several learned men; with his friend Father Mersenne, who formed a centre of scientific correspondence; with Fermat and Roberval ..."

${ }^{19}$ Les Lettres de Blaise Pascal, p. 182.
} 
At the center of this network of various scientists, and others, lied Marin Mersenne, who

"from 1620 to 1648, [kept] a vast and systematic scientific correspondence by which he maintained a flow of news of scientific discoveries and ideas between most of the leading scientists of the day. (...) as far apart as Sweden, Poland, and the Levant." 20

Did pascal know of Schickard through his father via Mersenne?

This is the question that was asked by historian of sciences Jean Itard in a book review from 1960, noting that the - by then published - large correspondence of Mersenne contained mentions of Schickard.

This seems plausible considering this is how he learned of Torricelli ${ }^{21}$.

\section{Scientific societies : social capital (3)}

The institution of the scientific society played an important role in our context :

Among them, Marin Mersenne's society, or group, was a major one ${ }^{22}$ : Academie Parisienne / Academia Parisiensis - created 1635.

He had "made his cell in the convent near Place Royale (now Place des Vosges) both a meeting place for scientific discussions and experiments" 23 .

Note these societies - some of them at least - seemed to have been much less sumptuous than current ones; and this may, or may not serve as lesson to our most distinguished current-day learned gentlemen and -women.

\footnotetext{
${ }^{20}$ New Cambridge Modern history 4, 141.

21 "To Pascal, who learned of Torricelli's work from Mersenne, this suggested a simple but striking test for the hypothesis: the air pressure, and therefore the height of the mercury, should be less at the peak of a mountain than at its foot. In 1648 the experiment was successfully carried out on the Puy-de-Dome by Florin Perier." [his brother-in-law] (New Cambridge Modern... 4, 157)

${ }^{22}$ qualified "important forerunner" to the French Academy of sciences in Encyclopedia of the Early Modern World.

${ }^{23}$ New Cambridge modern history 4, 141.
} 
They "met on Thursdays and [the event] was attended by the outstanding scientists and mathematicians of his day." 24

In 1666, the French Academy of Science was created, under Louis XIV, formalizing such societies. - but also bringing them under (State) control, and arguably making them inaccessible.

\section{V - Loss of father and sisters, and entourage}

In just one year Pascal lived to see the death of his father (1650), and the departure of his only remaining sister, Jacqueline (1651); while Gilberte had been married for almost ten years at that point.

For fear of overestimating we should not underestimate, and these facts should be seen as relevant background for his decision-making.

Through religion, in particular Port-Royal's variant of Jansenism, he found a way to deal with these events, we can assert.

In the letter written to Gilberte and her husband right after his father's death :

"We lost him the day he was baptized."

Preceded by a revocation of philosophy :

"Seneca and Socrates have nothing covincing to tell us on this occasion. (...) They all took death as natural (...) Does this not show

how weak Men are, if the greatest creations of the greatest among

them are so low and puerile.

Jesus-Christ, however, ...

Without [them] death is horrible, and horror within nature"

${ }^{24}$ Encyclopedia of the Early... vol. 4. See also Clere 1835. 
His father's death was suddenly put in a logical, coherent, and bearable perhaps too, context (at least temporarily);

While by later moving to Port-Royal, he got closer to Jacqueline. Gilberte, long married, was further out of reach.

Brunschvicg/Boutroux made the interesting remark that it was precisely when Jacqueline's fervor to enter the religious professions was the highest that her brother's worldly ambitions seem to have been the greatest ${ }^{25}$.

It should also be noted that this same period (end of 1640's, beginning of the 1650's) saw the death of Mersenne and Descartes; as well as the abdication of the Queen of Sweden;

Further isolating Pascal. Death, the ends of life, and connected topics, were not merely a theoretical subject at this point in the life of Pascal.

They lead straight to 1655 and provide another useful background for the moods and contents of the Pensees (in addition to Pascal's own health).

\section{VI - Etienne's injury (Rossellini's Pascal commented)}

In this dramatization, Etienne Pascal's injury coincides with a manifestation of Pascal's illness, and can be seen as a turning point :

During his father's treatment Blaise looses consciousness, and the (Jansenist) doctors examine him. Through Jacqueline, who tends to him, he receives from them St-Cyran's writings. [Segment 1]

Pascal's transition is most visible in a later segment, occurring apprx. 20 minutes afterwards, when, drawing water from a well, he enters an argument with his sister Jacqueline about his new-found views : his often mentioned "love of poverty", etc.. [Segment 2]

\footnotetext{
${ }^{25}$ Brunschvicg/Boutroux vol. $3: 25$.
} 
[Segment 'Doctor's visit']

- If we are indeed experts in anatomy, a science learned on the battlefields we know nothing of such afflictions ("humeur")... Here the Letters of Saint-Cyran, a French disciple of Jansen. They should leave the sick at no time.

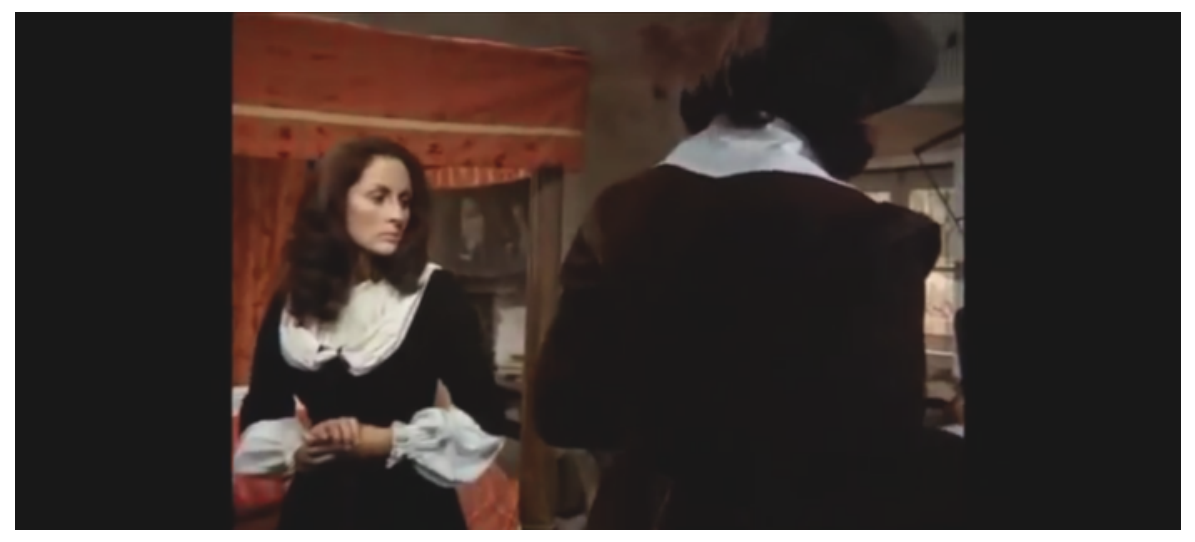

Figure 1: Doctor's visit (Blaise Pascal)

[Segment 'Argument at the well']

- But, why not have your valet do it? You tire yourself without reason...

- I have a wish for poverty :

Actions are worth more than any discourses, in this regard.

- But, you forget that poverty which affects the mind!

And, until now you did not seem to care to cultivate such a disposition,

neither in your actions, nor your thoughts. Is this not one of your contradictions?

- ... emptiness is only a representation of infinity.

("le vide n'est que la figure de l'infini")

... Do you ever love someone by reason alone?

In Rossellini's Blaise Pascal, Etienne's leg seems to be injured; while the doctors are the "Deschamps" brothers.

Continuing this theme of historical (in)accuracy :

The "Letters of Saint-Cyran" could refer either to letters received or sent by the abbot of Saint-Cyran; 
in the former case La naissance du jansenisme decouverte, published in 1654, was a notable work as it contained Jansen's letters to Saint-Cyran - some of the most important documents when it comes to the reception of Jansen's ideas.

Though this would not fit the chronology, Etienne's injury happened much earlier.

Most likely the Lettres chretiennes are meant, published in the 1640's (fitting with the events). [S-C sent a lot of letters to a lot of people $]^{26}$

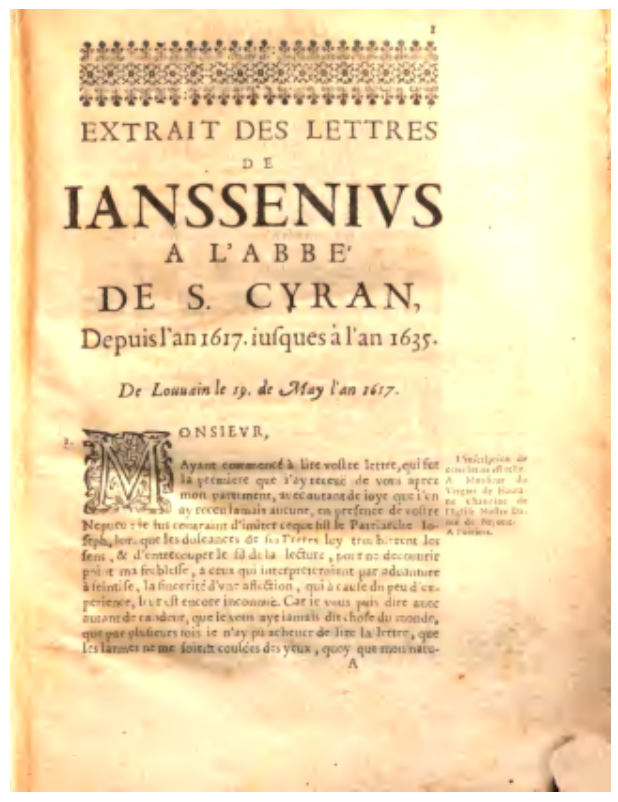

Figure 2: Jansen - Saint-Cyran letters... (1654, Leuven)

(And, when one of the doctors claims to have learned his science, medicine or anatomy, on the fields of battle, he almost certainly means the Thirthy Years War, which by the time of Etienne's injury was still raging on...)

\footnotetext{
${ }^{26}$ For a discussion of this, see Bremond 1967, in particular vol. 4 : 85-86; 46... [Bredmond's appraisal of Saint-Cyran is at least on par with Condorcet's evaluation of Pascal.]
} 


\section{* Sociology of the Father Mersenne}

On the social spectrum, Mersenne represents the exact opposite of Pascal, with his upper-class origins, and father mathematician (in short, the very unsurprising origins of too many mathematicians to $\operatorname{count}^{27}$ );

Called agreably "“gentlemen of private means"" in textbooks by respectable historians... ${ }^{28}$.

(What one should call "bourgeois-friendly" history textbooks in a parallelism with the "white-oriented" ones critized by the well-known historian from Boston.)

As such, our Pere Mersenne merits a more detailed portrait :

His father was a farmer, and it was through education - a very good Jesuit school - that he was able to become more than he should have.

The same school of La Fleche, supported by Henri-IV, that Descartes would also later attend ${ }^{29}$.

This school had the characteristic - shared with all Jesuit schools - of being free of charge (for pupils who lived outside i.e. "externe");

A feature that permitted Jesuits to attract pupils ${ }^{30}$, and which made them attractive for lower-class folks. (Something that created discontent amongst those who opposed the Jesuits / were proponents of a paid education (for the rich)).

Mersenne happened to live 5 leagues ["lieue"] from that School ${ }^{31}$ (about 10 miles or $15 \mathrm{~km})$.

Following this and two years of further studies at the Sorbonne ${ }^{32}$, thus joined

\footnotetext{
${ }^{27}$ whose sociological regularities are almost as strong as their mathematical laws... (contra whatever Romantic notions of exceptionalism, and even "genius" they may entertain... Like some animals, who, looking at their reflection, do not recognize themselves...)

${ }^{28}$ New Cambridge Early Modern history 4, 133.

${ }^{29} 3$ months later (Clere 1853 : 108).

${ }^{30}$ Clere 1853: 86.

${ }^{31}$ Clere $1853: 108$

${ }^{32}$ Encyclopedia of the Early... vol. 4.
} 
the religious professions : the closest to an intellectual profession for those who were not financially independent, like the aforementioned bourgeois philosophers...

Specifically Mersenne chose a mendicant order (called "minim", or "very small') which is to say the type that were closest to people (they had to be, to receive donations) and lived by vow of poverty.

[A better known such group is the order of Saint Francis, the so-called "Franciscans".]

In this 17th century, Mersenne is to mathematics what Racine is to letters...; While Moliere in turn was much closer to Pascal in terms of social origins, as were most other writer-philosophers (including Montaigne, Condorcet, Marquis, La Rochefoucauld, "prince", etc.).

It takes not only a solid mind do science or to write, it also takes time, and that time must be paid for somehow — inheritance or work permitting spiritual activities...

As soon as Mersenne had a stable position (were are told he became a teacher in the convent in 1614, first in the province then in Paris, 1619), he could begin his prolific scientific activities, both as a maker of science and arguably even more importantly as a relay of scientific communication.

If the Encyclopedie, as we had already proposed, prefigured some sort of Internet / Web; Mersenne was more like a router or node of information, a principal, very active ${ }^{33}$ one.

And, if the Port-Royal logic was the most fascinating and underestimated work of this period, then Mersenne is its most intriguing yet barely known figure.

\footnotetext{
${ }^{33}$ The editors of the New Cambridge Modern History call him "indefatigable" $(5,47)$.
} 


\section{Afterword}

Condorcet concluded in his strange 'Eloge' :

"Pascal had reached a point of perfection : [he needed] to love no one, and wanted to be loved by no one."

However right he was, Pascal reminds us of our modern heroes of the 21st century the most [which we would rather reference than produce yet another copy of Brueghel and Ruben's five senses paintings]...

As we must all, after all, live in our century. - Pascal had lived in his own, the 17 th.

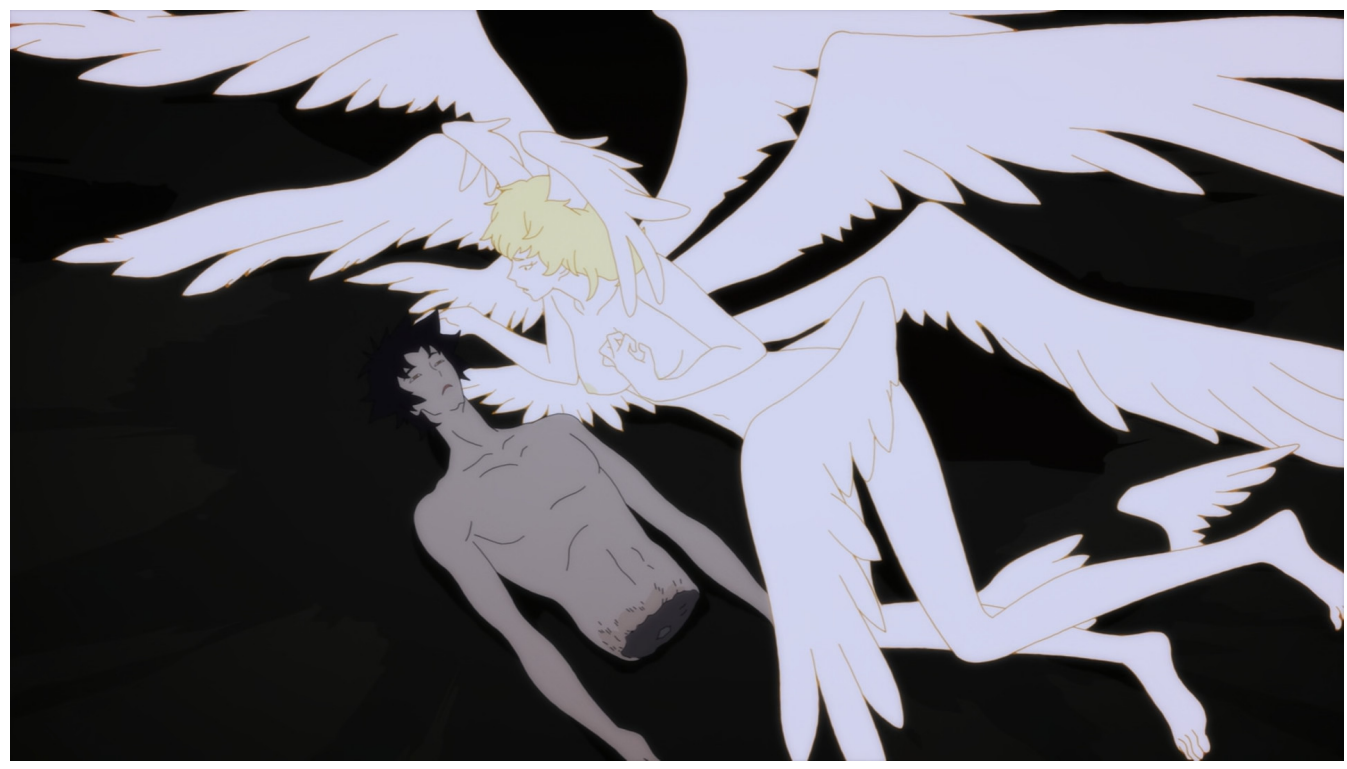

("Why is it that I feel something now...") 


\section{Bibliography, partial}

\section{Primary sources}

Pascal, Blaise.

- 1651. 17th of October. 'Letter to Mr. and Mrs. Perier' [Father's death] e.g. Brunschvicg/Boutroux vol. 2 : 537ff..

- 1652. C. June. 'Letter to Christina, Queen of Sweden'. e.g. Brunschvicg/Boutroux vol. 3 : 25ff..

- 1654. 27th of October. ['Letter to Fermat'] e.g. Brunschvicg/Boutroux vol. 3 : 429ff..

(The first four volumes of Oeuvres are generally relevant for this period.)

-. 1922. Les Lettres de Blaise Pascal ['together with those of his correspondants']. Ed. Cres.

(About 50 letters. The editors prefaced this compilation with the words "Even though the Provincials and the Pensees are in every hands, the whole of the correspondence of Blaise Pascal remains little known to the public. ..."; the Oeuvres, these editors note, have the entirety of the letters - but it sure is nice to have them in one small book, rather than split over many volumes)

Bourdelot.

- 1644. 26th of February. 'Letter from Bourdelot to Pascal'. [Invitation to see the Prince of Conde]

e.g. Brunschvicg/Boutroux Oeuvres 1: 283.

- 1652. 14th of May. 'Letter from Sweden, Bourdelot to Pascal'. [Regarding the Queen]

e.g. Brunschvicg/Boutroux vol. $3: 27-8$.

Descartes.

- 1647. 13th of December. 'Letter to Mersenne' [about Pascal] e.g. Les Lettres de Blaise Pascal, appendix 1.

* Brueghel - Rubens. Early 17th c.. Sight.

(Instruments, maps, globes on one side; art on the other. Desire to know, and see...)

* Harvey. 1628. On the motion of the heart and blood in animals

(In his writings on infinity, (Pensees), Pascal evoked the composition of blood, as part of developments on what cannot be seen through "common senses" (MS c p 348).) 
* Jansen - Saint-Cyran correspondence. In : 1654. La naissance du jansenisme decouverte ['The Birth of Jansenism discovered']. Louvain.

(Contains also some more minor letters sent by others, at the end.)

* Saint-Cyran. 1640's. Lettres chretiennes et spirituelles. (multiple editions)

Brief remarks on English translations

- An English translation of the Faugere ed. of the Pensees was available at the latest by 1885 (done by a C. K. Paul)

[gathered from the bibliography of The Cambridge Modern History]

- An English translation of the Lettres Provinciales was available at the latest by 1880 (De Soyres).

[the editors of The Cambridge Modern History were aware of it as well]

\section{Bibliography}

- Bremond, Henri. Histoire du sentiment religieux en France. Many vol..

-. 1967. Vol. 4. Colin.

(Ch. 3, 4, 5 are about Saint-Cyran.)

- Cavailles, Jean. ['Axiomatic method and formalism']. Ch. 1, 66 ff..

(On Pascal's theorem, Desargues' theorem (and Hilbert))

- Clere, Jules. 1853. Histoire de l'Ecole de La Fleche... / 'History of the School at La Fleche, from its foundation by Henri IV to...'. Jourdain.

(In particular ch. 3, "The old college under the Jesuits (1604-1622)", and even more so the section "Descartes and Mersenne", in inverted order of attendance, (comparatively little on Mersenne))

- Condorcet. 1847. Oeuvres. Many vol.. Firmin etc..

- Vol. 3. (For the strange "eloge", eulogy of Pascal - whose preface is an absolute riot, so much so the editors weighed whether to remove it)

-. Vol. 2. (For the eloge of Roberval)

- (ed.) Pensees.

- Dieudonne, Jean. 1974. Cours de geometrie algebrique. T. 1 "Apercu historique...". PUF.

(Bourbaki group member. The history of algebraic geometry from Antiquity to today. Divisions into 7 periods. Contains developments on Desargues, Pascal...)

[An English translation is available under the title History of algebraic geometry.]

- Itard, Jean. 1960. "Correspondance du P. Marin Mersenne, religieux minime, t. V (1635)" Revue d'histoire des sciences 13(4) : 355-357.

(Book review in which Itard makes the important note that Mersenne's large correspondence included some with Schickard, spelled "Schickart". When he addresses "the historians of such [computing] machines", and prompts them to 
research further, with little doubt he must have had Rene Taton in mind (who headed the journal and whose domain it was))

- Ostermann / Wanner. 2012. Geometry by its history. Springer.

- Rossellini, Roberto. 1972. Blaise Pascal.

(The commented scenes happen at c. 40 min. and 1 hour, respectively.)

-. 1966. The Taking of Power by Louis XIV.

-. 1972. Augustine of Hippo.

-. 1974. Cartesius.

(by the same director, also relevant; part of his historical (TV) films period. Preceded by Francis a.o.)

- The Cambridge Modern History. Cambridge Press.

—. 1906. Vol. 4: "The Thirty Years' War".

—. 1908. Vol. 5: "The age of Louis XIV". (ch. 23 : "European science...")

- The New Cambridge Modern History. Cambridge Press.

- 1970. Vol. 4 : "The Decline of Spain and the Thirty Years War 1609-48".

-. 1922. Vol. 5 : "The ascendancy of France 1648-88".

\section{Illustrations}

Devilman Crybaby (Science Saru)

Castlevania: Symphony of the Night (Konami) 


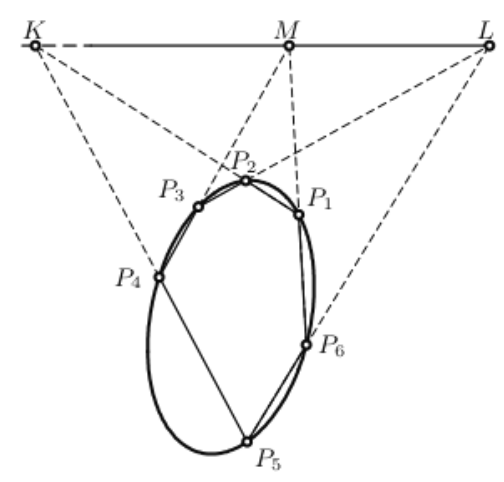

Figure 3: Drawing by Ostermann / Wanner

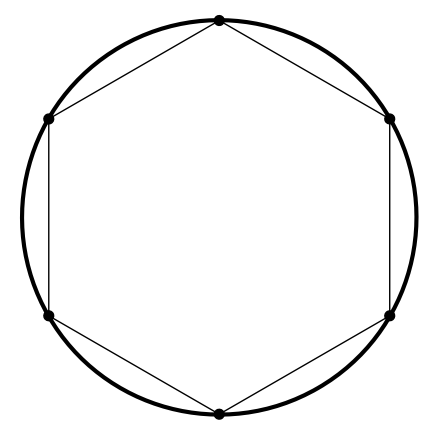

(A most special case : a regular hexagon inscribed in a circle) 


\section{PRIVILEGE}

POUR LA MACHINE ARITHMETIQUe dE M. PASCAL

Louis, par la grace de Dieu, roy de France et de Navarre, á nos amez et feaux Cons ${ }^{\text {rs }}$ les gens tenans nos Cours de Parlement, $M^{\text {es }}$ des Resquestes Ordinaires de nostre hostel, Baillifs, Senechaux, Prevôts, leurs Lieutens et tous autres nos justiciers et officiers qu'il appartiendra, salut. Notre cher et bien améle $S^{r}$ Pascal nous a fait remontrer qu'àl'imitation du $S^{r}$ Pascal, son pere, notre Cons ${ }^{\mathrm{r}}$ en nos conseils, et president en notre Cour des Aydes d'Auvergne, il auroit eu, des ses plus jeunes années, une inclination particuliere aux sciences Mathematiques, danslesquelles, par ses etudes et ses observations, il a inventé plusieurs choses, et particulierement une machine, par le moyen de laquelle on peut faire toutes sortes de supputations, Additions, Soustractions, Multiplications, Divisions, et toutes les autres Regles d'Arithmetique, tant en nombre entier que rompu, sans se servir de plume ni jettons, par une methode beaucoup plus simple, plus facile à apprendre, plus promple à l'execution, et moins penible à l'esprit que les autres façons de calculer qui ont esté en usage jusqu'à present; et qui, outre ces avantages, a encore celuy d'estre hors de tout danger d'erreur, qui est la condition la plus importante de toutes dans les calculs. De laquelle machine il auroit fait plus de cinquante modeles, tous differens, les uns composez de verges ou lamines droites, d'autres de courbes, d'autres avec des chaisnes; les uns avec des roüages concentriques, d'autres avec des excentriques, les uns mouvans en ligne droite, d'autres circulairement, les uns en cones, d'autres en cylindres, et d'autres tout differens de ceux-là, soit pour la matiere, soit pour la figure, soit pour le mouvement: de toutes lesquelles 